\title{
Lectio praecursoria: Diplomatins ideal och praktik. Utländska sändebud i Stockholm 1746-1748
}

\author{
Sophie Holm
}

FM Sophie Holms doktorsavhandling Diplomatins ideal och praktik. Utländska sändebud i Stockholm 1746-1748 framlades för offentlig granskning vid Helsingfors universitet den 13 december 2019. Opponent var professor Daniel Riches (University of Alabama) och kustos professor Henrik Meinander (Helsingfors universitet). Avhandlingen finns tillgänglig i elektroniskt format: http://urn.fi/URN:ISBN:978-951-51-5691-4.

Den populära tv-serien The Crown skildrar i ett av sina avsnitt prinsessan Margarets resa till USA 1965. I The Crowns skildring av händelserna charmar Margaret president Johnson under en middag på Vita huset, vilket tar den amerikansk-brittiska relationen ur ett spänt läge och bäddar för ett amerikanskt stöd för ett brittiskt lån från Internationella valutafonden. När drottningen under ett samtal med prins Philip berömmer Margarets förmåga, intelligens och stil och överväger att utöka systerns roll, avråder Philip henne. "She may have had a success in Washington", säger han, "but let's not delude ourselves that serious diplomacy can be achieved through drinking and dancing". Seriös diplomati är inte danser och dryck. Låt Margaret få äran, fortsätter han, men vi kan inte skriva om reglerna.

I den här lilla fiktiva samtalssnutten kondenseras mycket information kring utrikespolitik och diplomati. Prins Philips förkastande av prinsessan Margarets framgång och kritik av henne val av diplomatisk taktik blottar uppfattningen om att det finns riktig diplomati och något som inte är det. Men kan dans och drycker verkligen a priori förkastas som diplomatiska metoder? Ur ett tidigmodernt perspektiv ter sig detta inte uppenbart. Tvärtom framstår ett bruk av aktörer utan formell diplomatisk status och ett utnyttjande av situationer utanför det formella förhandlingsbordet på intet vis exceptionellt. Det jag vill peka på i den här scenen är emellertid inte frågan om vad som är diplomati utan snarare hur aktörer bedöms: vad som uppfattas som taktfull diplomati och vad som inte gör det samt det faktum att positiv eller negativ kritik inte bör likställas 
med faktiska framgångar eller misslyckanden. Prinsessan Margarets framgång i The Crown-avsnittet var, när allt kommer omkring, uppenbar.

När någon bryter mot en regel kan ett sådant fall analyseras från olika perspektiv. För det första kan vi intressera oss för normbrytarens intentioner, till exempel de politiska intentionerna bakom ett beteende som kan uppfattas som avvikande och uppseendeväckande, provokativt eller till och med offensivt. För det andra kan vi intressera oss för reaktionerna hos dem som agerar dömande och fråga oss varför just en part reagerar som den gör. För det tredje kan vi försöka analysera normbrottet ur den normativa grundens synvinkel och fråga oss enligt vilken logik en handling upplevdes vara normbrytande. Även om kritiken inte nödvändigtvis berättar något om faktiska felsteg är den inte slumpmässig.

En inkörsport till normativa förväntningar är konfliktsituationer som genererar kritiska bedömningar av inblandade parter. Jag har i min avhandling undersökt diplomati som en social praktik skapad av enskilda aktörer. Det innebär att jag sett på 1700-talets diplomati som ett värv styrt av implicita sociala normer vid sidan av ett explicit regelverk i form av folkrätt och diplomatiskt protokoll. En av inkörsportarna till granskningen har varit en diplomatisk incident med särskilt långvariga följder: den så kallade Springeraffären som ledde till en sextonårig paus i de officiella svensk-brittiska diplomatiska relationerna. Konflikten utbröt i slutet av 1746-1747 års svenska riksdag efter att den svenska köpmannen Christoffer Springer, häktad för att ha motarbetat tronföljden, hade flytt till den brittiska beskickningen i Stockholm, där han möjligtvis hade kunnat erbjudas diplomatisk asyl. Eftersom det brittiska sändebudet, Guy Dickens, ansåg att han tvingades lämna ut Springer med våld uppstod en tvist kring huruvida hans diplomatiska immunitet blivit kränkt eller inte.

Genom ett fokus på bland annat Springeraffären har jag granskat 1700-talets diplomatiska praktik och dess normativa ramverk i en specifik geografisk och politisk kontext. Jag har fokuserat på utländska sändebud i Stockholm under åren kring riksdagen 1746-1747 och diskuterat kopplingen mellan diplomati, opinionsbildning och konflikthantering på mikronivå.

Om vi bortser från den avbrutna brittisk-svenska relationen är ifrågavarande riksdag ingen vattendelare i svensk utrikespolitisk historia. De allianser Sverige slöt med Preussen och Frankrike under denna riksdag ökade stödet för den redan nära relationen till Frankrike. Ur svensk synvinkel kan det te sig märkvärdigt att intressera sig för just den här riksdagen. Däremot utgör Stockholm som diplomatisk arena vid den här tidpunkten ett spännande studieobjekt för frågeställningar kring diplomatiska kulturer i 1700-talets Europa. Det var nämligen inte enbart den brittiska beskickningen som råkade i konflikt med den svenska statsledningen. Även relationen mellan statsledningen och den ryska beskickningen var spänd och ledde till ett byte av ryskt sändebud i Stockholm. Det finns med andra ord en hel del diplomatiska mikrokonflikter, små tvister kring exempelvis ceremoniel och förhandlingssätt, som kan granskas just med anknytning till denna riksdag. Därtill skapade det svenska frihetstida statsskicket en miljö för diplomatisk verksamhet som avvek från många andra hov- och huvudstäder i Europa.

Sändebud som anlände till Stockholm möttes exempelvis av ceremonier där det svenska rådet innehade en betydelsefull roll. Det här är anmärkningsvärt med tanke på tidigare forsknings beskrivning av den frihetstida svenska monarkin, där kungamakten förvisso var svag men anses ha varit oumbärlig med tanke på rikets heder och 
oavhängighet utåt sett. Min granskning av rådets roll i det ceremoniella umgänget med diplomatkåren antyder att statsledningen i Sverige var mån om att påminna representanter för utländska makter om den svenska författningens säregenheter. Även ur språklig synvinkel innehade den svenska administrationen vissa särdrag. Sveriges formella, utrikespolitiska relationer fördes på ett flertal språk, vilket syntes bland annat i skiftande språkval i de fördrag Sverige slöt med utländska makter. Diplomatin i Stockholm karakteriserades av en liknande flerspråkighet inom den formella kommunikationen mellan beskickningar och svenska myndigheter. Detta nyanserar bilden av 1700-talets europeiska diplomati som i mångt och mycket franskspråkig.

Utländska beskickningar i 1700-talets Stockholm har tidigare undersökts framför allt genom sina kopplingar till och sitt stöd för svenska politiska grupperingar. Genom ett fokus på diplomatins implicita normer har jag strävat efter att skapa ett alternativt narrativ kring utländska sändebud i frihetstidens Sverige. Om vi skärskådar sändebuds beskrivningar av sitt eget arbete och kritiska granskningar av kollegers agerande, ser vi i vilken mån diplomatkåren de facto påverkades av motstridiga förväntningar: samtidigt som de utländska beskickningarna i Stockholm skulle upprätthålla specifika utrikespolitiska intressen förväntades de även agera opartiskt. Den senare förväntningen betydde inte att sändebud avstod från att ta parti i förtroliga samtal eller genom att understöda politiska fraktioner finansiellt. Snarare gällde opartiskheten ett agerande i det offentliga och det formella umgänget med övriga sändebud, de svenska hoven och övriga politiska instanser. Detta syns tydligt både i kritik riktad mot diplomatiska kolleger som upplevdes ha agerat allt för partiskt och i självberöm med anledning av en uppnådd opartiskhet.

Potentiellt motstridiga förväntningar på hur tjänstemän skulle agera var enligt den tyska historikern Hillard von Thiessen typiska för ett tidigmodernt samhälle präglat av parallella normsystem. Denna normkonkurrens gav upphov till normativa gråzoner som öppnade upp för situationsbundna tolkningar och som kunde utnyttjas som politiska vapen. Under 1746-1747 års riksdag kritiserades särskilt det brittiska och det ryska sändebudet i Stockholm för att agera partiskt i situationer då opartiskhet var att föredra och för att på andra vis agera uppseendeväckande. Samma sändebud understödde en svensk, politisk gruppering i underläge, det antifranska mösspartiet. I en dylik politisk situation blev ifrågavarande beskickningar ett tacksamt objekt för diplomatiska kollegers dömande blick och ett logiskt mål för den svenska statsledningens kritik.

Springeraffären handlade inte, menar jag, i första hand om den komplicerade frågan om diplomatisk asyl. Den uppstod inte i första hand som en följd av en juridisk oenighet utan var framför allt en följd av upprepade tvister i den diplomatiska vardagen, den inblandade beskickningens koppling till en svensk, politisk opposition och de spänningar som uppstod i växelverkan mellan diplomati och offentlig debatt. Det avgörande i konflikten var nämligen bland annat det faktum att skrivelser från den brittiska beskickningen i Stockholm spred sig i utländska tidningar, vilket upprörde den svenska regeringen. Konflikten speglade med andra ord många av den diplomatiska praktikens spänningar mellan förväntan och verklighet: Guy Dickens agerande bröt mot en förväntad diskretion samtidigt som hans öppna ställningstagande i Springers rättsfall sågs som en bristande opartiskhet. Tystnadsbrottet och Guy Dickens vägran att glömma tidigare tvister med svenska myndigheter bidrog till att konflikten eskalerade. 
Incidenten pekar sammanfattningsvis på ett flertal känsliga frågor inom 1700-talets diplomati.

En uppmärksam åhörare har lagt märke till att jag inte har använt ordet diplomat utan i stället valt den mer tidstypiska beteckningen sändebud. Begreppet diplomati existerade de facto inte under största delen av 1700-talet. Det myntades först i slutet av seklet på franska och spreds därefter till andra europeiska språk. I tidigmoderna teoretiska verk kring det som vi kallar för diplomati talade man i stället om konsten att förhandla eller om det perfekta ambassadörsidealet. I det här sammanhanget utgör 1700-talet en övergångsperiod i den europeiska diplomatins historia: en övergång från tidigmodern till modern diplomati. Under seklet fanns fortfarande varken enhetliga utrikespolitiska administrationer eller en professionaliserad diplomati, men under seklets gång inrättades utrikesministerier i flera länder, och det förekom försök till diplomatiska utbildningar.

Vilka förväntningar som ställdes på diplomatiska aktörer är därmed en relevant fråga med tanke på uppfattningen om en övergångsperiod. Vi kan fråga oss vad diplomati upplevdes vara på 1700-talet och vad som avgjorde ett diplomatiskt handlandes sociala gränser. Med den här undersökningen har jag velat visa att det förekom yrkesspecifika normativa förväntningar även om diplomatin inte ännu var professionaliserad på samma sätt som under modern tid. Det tiotal sändebud som tjänstgjorde i Stockholm vid 1740-talets mitt hade varierande bakgrunder: vissa hade tjänstgjort inom armén, vissa hade en stark koppling till det hov de representerade, vissa ägnade så gott som hela sitt yrkesverksamma liv till diplomatiska uppdrag, medan ett av sändebuden snarast var en representant för 1700-talets gränsöverskridande lärda gemenskap. Trots olika bakgrund, bedömde de varandra enligt samma kriterier för vad som var diplomatiskt taktfullt. Likheten mellan retoriken i deras rapporter och språket i diplomatiska manualer från samma tidsperiod är tidvis frapperande.

De normativa förväntningar som ställdes på sändebud spelade en roll inte enbart med tanke på utvecklingen av en diplomatisk professionalitet. Forskning har under de senaste åren lyft fram den betydande roll kvinnor kunde ha inom tidigmoderna diplomatiska situationer. Förutom medlemmar av kungafamiljer gällde detta bl.a. kungliga mätresser, hovdamer och ambassadörshustrur, som tidvis kunde påverka diplomatiska förhandlingar mycket direkt. Det som studier i den här typen av informella, diplomatiska aktörer inte lyfter fram är orsaken till att de informella aktörerna över huvud taget behövdes. Jag anser att det här behovet är nära kopplat till den tidigmoderna diplomatins normativa grund och de formella diplomatiska aktörernas spelrum. Genom att utstaka gränserna för diplomatin som social praktik förstår vi med andra ord bättre varför det också behövdes informella aktörer.

Diplomatiska felsteg befinner sig i knutpunkten mellan implicita normer och politiska förvecklingar. Att lösgöra diplomatin som historiskt fenomen från en allt för anekdotisk historieskrivning förutsätter att vi ser både på det institutionella ramverket vilket både traditionell och ny diplomatihistoria gjort - och på det normativa spelrum inom vilket tidigmoderna sändebud rörde sig när de manövrerade mellan hov, politiska institutioner och lokalsamhälle. Det handlar om att skriva diplomatins kulturhistoria, vilket i sig är en balansgång som kräver ett taktfullt sinne och ett diplomatiskt öga för försvarstal: detta perspektiv kan nämligen på samma gång uppfattas som den händelsefokuserade histoire événementielle som Annalesskolan och generationer efter den kritiserat så starkt och som alldeles för händelselös för att verkligen handla om 
diplomati. Kan man, och får man, skriva om diplomati utan att fokusera på politiska intressen och beslut, inte ens i formen av beslutsprocesser? Med min undersökning har jag strävat efter att besvara denna fråga jakande.

FM (disp.) Sophie Holm

historia, Helsingfors universitet

sophie.holm (apud) helsinki.fi

\section{Litteratur}

Om diplomatihistoria under 2000-talet, särskilt kultur- och socialhistoriska perspektiv på tidigmodern diplomati:

- Hellsing, My \& Sophie Holm, "Tidigmodern utrikespolitik som kulturhistoria? En presentation av forskningsfältet 'new diplomatic history'”, Historisk Tidskrift för Finland 100:4 (2015), 549-560.

- Lehmkuhl, Ursula, "Diplomatiegeschichte als internationale Kulturgeschichte: Theoretische Ansätze und empirische Forschung zwischen Historischer Kulturwissenschaft und Soziologischem Institutionalismus", Geschichte und Gesellschaft 27 (2001), 394-423.

- Lindemann, Mary, "The Discreet Charm of the Diplomatic Archive", German History 29:2 (2011), 283-304. https://doi.org/10.1093/gerhis/ghr042

- Osborne, Toby \& Joan-Pau Rubiés, "Introduction. Diplomacy and Cultural Translation in the Early Modern World", Journal of Early Modern History 20:4 (2016), 313-330. https://doi.org/10.1163/15700658-12342502

- Riches, Daniel, Protestant Cosmopolitanism and Diplomatic Culture. Brandenburg-Swedish Relations in the Seventeenth Century. Northern World 59. Leiden 2013. https://doi.org/10.1163/9789004240803_002

- Schweizer, Karl W. \& Matt J. Schumann, ”The Revitalization of Diplomatic History. Renewed Reflections", Diplomacy and Statecraft 19:2 (2008), 149-186. https://doi.org/10.1080/09592290802096174

- Sowerby, Tracey A., "Early Modern Diplomatic History", History Compass, 14:9 (2016), 441-456. https://doi.org/10.1111/hic3.12329

- Sowerby, Tracey A. \& Jan Hennings (eds.), Practices of Diplomacy in the Early Modern World c.1410-1800. Abingdon 2017. https://doi.org/10.4324/9781315186375

- $\quad$ von Thiessen, Hillard \& Christian Windler (Hrsg.), Nähe in der Ferne. Personale Verflechtung in den Außenbeziehungen der Frühen Neuzeit, Beiheft der Zeitschrift für Historische Forschung 35 (2005).

- $\quad$ von Thiessen, Hillard \& Christian Windler (Hrsg.), Akteure der Außenbeziehungen. Netzwerke und Interkulturalität im historischen Wandel. Köln \& Wien 2010. https://doi.org/10.7788/boehlau.9783412212698

- Watkins, John, "Toward a New Diplomatic History of Medieval and Early Modern Europe", Journal of Medieval \& Early Modern Studies 38:1 (2008), 114. https://doi.org/10.1215/10829636-2007-016 
Om begreppet normkonkurrens:

- von Thiessen, Hillard, "Korruption und Normenkonkurrenz. Zur Funktion und Wirkung von Korruptionsvorwürfen gegen die Günstling-Minister Lerma und Buckingham in Spanien und England im frühen 17. Jahr-hundert”, Jens Ivo Engels, Andreas Fahrmeir \& Alexander Nützenadel (Hg.), Geld - Geschenke Politik. Korruption im neuzeitlichen Europa. Historische Zeitschrift, Beiheft 48. München 2009, 91-120. https://doi.org/10.1515/9783110650792-005

Om 1700-talet som en övergångsperiod inom europeisk diplomati:

- von Thiessen, Hillard, "Diplomatie vom type ancien. Überlegungen zu einem Idealtypus des frühneuzeitlichen Gesandtschaftswesens", Hillard von Thiessen \& Christian Windler (Hrsg.), Akteure der Außenbeziehungen. Netzwerke und Interkulturalität im historischen Wandel. Köln \& Wien 2010, 471-503. https://doi.org/10.7788/boehlau.9783412212698.471

Om kvinnors roll inom tidigmodern utrikespolitik:

- Bastian, Corina, Eva Dade \& Eva Ott, "Weibliche Diplomatie? Frauen als außenpolitische Akteurinnen im 18. Jahrhundert, Corina Bastian, Eva Kathrin Dade, Hillard von Thiessen \& Christian Windler (Hg.), Das Geschlecht der Diplomatie. Geschlechterrollen in den Außenbeziehungen vom Spätmittelalter bis zum 20. Jahrhundert. Köln 2014, 103-114. https://doi.org/10.7788/boehlau.9783412216719.103 